\title{
The ThPG1 Endopolygalacturonase Is Required for the Trichoderma harzianum-Plant Beneficial Interaction
}

\author{
Eugenia Morán-Diez, ${ }^{1}$ Rosa Hermosa, ${ }^{1}$ Patrizia Ambrosino, ${ }^{2}$ Rosa E. Cardoza, ${ }^{3}$ Santiago Gutiérrez, ${ }^{3}$ \\ Matteo Lorito, ${ }^{2}$ and Enrique Monte ${ }^{1}$ \\ ${ }^{1}$ Centro Hispano-Luso de Investigaciones Agrarias (CIALE). Departamento de Microbiología y Genética, Universidad \\ de Salamanca, Campus de Villamayor, C/ Duero 12. 37185 Salamanca, Spain; ${ }^{2}$ Dipartamento di Arboricoltura, Botanica \\ e Patologia Vegetale, Università degli Studi di Napoli Federico II, Via Università 100, 80055 Portici (NA), Italy; ${ }^{3}$ Área \\ de Microbiología, Escuela Universitaria de Ciencias de la Salud. Universidad de León, Campus de Ponferrada, \\ Avda. Astorga s/n. 24400 Ponferrada, Spain
}

Submitted 14 November 2008. Accepted 14 April 2009.

Considering the complexity of the in vivo interactions established by a mycoparasitic biocontrol agent at the plant rhizosphere, proteomic, genomic, and transcriptomic approaches were used to study a novel Trichoderma gene coding for a plant cell wall (PCW)-degrading enzyme. A proteome analysis, using a three-component (Trichoderma spp.-tomato plantlets-pathogen) system, allowed us to identify a differentially expressed Trichoderma harzianum endopolygalacturonase (endoPG). Spot 0303 remarkably increased only in the presence of the soilborne pathogens Rhizoctonia solani and Pythium ultimum, and corresponded to an expressed sequence tag from a $T$. harzianum T34 cDNA library that was constructed in the presence of PCW polymers and used to isolate the Thpg1 gene. Compared with the wild-type strain, Thpgl-silenced transformants showed lower PG activity, less growth on pectin medium, and reduced capability to colonize tomato roots. These results were combined with microarray comparative data from the transcriptome of Arabidopsis plants inoculated with the wild type or a Thpg1-silenced transformant (ePG5). The endoPG-encoding gene was found to be required for active root colonization and plant defense induction by $T$. harzianum T34. In vivo assays showed that Botrytis cinerea leaf necrotic lesions were slightly smaller in plants colonized by ePG5, although no statistically significant differences were observed.

Most species of Trichoderma have been linked to biocontrol and biotechnological applications. The versatility of Trichoderma strains to suppress diseases caused by pathogens has been further illustrated (Howell 2003; Papavizas 1985). Their antagonistic abilities are described as a combination of several mechanisms, including nutrient competition and direct mycoparasitism, which involves the production of antifungal metabolites and cell wall (CW)-degrading enzymes (Howell 1998; Kuc 2001). The capacity of this fungus

Corresponding author: E. Monte; Telephone: +34 923294500 (ext. 5119); Fax: + 34923 294399; E-mail: emv@usal.es

Nucleotide sequence data is available from the GenBank database under accession numbers AM421521 (Thpg1 gene) and AM489729 (promoter).

* The $e$-Xtra logo stands for "electronic extra" and indicates that four supplemental figures are published online. to promote growth and induce resistance in plants has also been described (Yedidia et al. 1999). In this sense, Trichoderma spp. can generate a response in the plant similar to rhizobacteria-induced systemic resistance (ISR), as has been demonstrated by following different research approaches (Alfano et al. 2007; Djonovic et al. 2007; Shoresh and Harman 2008). Some CW oligomers may act as elicitor molecules released by plants following pathogen attack (Woo et al. 2006). These can include oligogalacturonides (OGA), biologically active homogalacturonan (HGA) fragments with a size between 2 and 20 residues of galacturonic acid. OGA released from pectins are related to defense responses and also modulate plant growth and development (Casasoli et al. 2008; Ridley et al. 2001).

Pectin is a major component of plant $\mathrm{CW}$ and pectinases are among the first enzymes produced during fungal attack on the plant (Annis and Goodwin 1997). These enzymes are involved in the cleavage of the three pectin domains: HGA, rhamnogalacturonan-I (RG-I), and rhamnogalacturonan-II (RG-II) (Willats et al. 2001). Endopolygalacturonases (endoPG) catalyze the hydrolysis of $\alpha$-1,4-galacturonic acid linkages between two nonmethylated galacturonic acid residues from HGA. EndoPG are included in family 28 of the glycosyl hydrolase enzymes (E.C. 3.2.1.15) (Henrissat 1991) that, in general, use pectin as substrate (Wubben et al. 2000).

Several fungal endoPG have been purified and characterized (D'Ovidio et al. 2004a) and their role during plant pathogenesis has been investigated (Di Pietro and Roncero 1998; Roper et al. 2007; ten Have et al. 2001). To date, only two endoPG from Trichoderma reesei (Mohamed et al. 2003) and one from T. harzianum (Mohamed et al. 2006) have been purified in Trichoderma spp. but no gene coding for these proteins have been isolated yet. In fact, the genus Trichoderma is today considered an avirulent plant-symbiotic fungus (Harman et al. 2004) and studies focused on genes and proteins directly involved in plant-Trichoderma interaction are still relatively uncommon (Woo et al. 2006).

Using proteomic, genomic, and transcriptomic approaches, in the present work, we report for the first time the cloning and characterization of a gene, Thpgl, that encodes an endoPG protein from a Trichoderma sp. strain. We show that this gene is differentially upregulated during Trichoderma spp.-plantpathogen interaction. Silencing of Thpgl resulted in a significant decrease of endoPG and root colonization activities in the biocontrol fungus and in a reduced expression of genes related to defense in the plant. 


\section{RESULTS}

\section{Proteomic analysis.}

A proteomic approach was used to investigate the cell protein profiles of T. harzianum T34 in order to identify differentially expressed proteins during Trichoderma spp.-plant-pathogen interactions. Two-dimensional electrophoresis (2-DE) maps of intracellular proteins were generated from mycelium obtained by growing Trichoderma spp. in a three-component system with tomato plantlets, T. harzianum T34, and a fungal or Oomycete plant pathogen (Fig. 1). The proteome of T. harzianum T34, obtained on water agar (WA) in the presence of the plant, was used as a control for comparisons. Differential spot numbers produced according to PD-Quest analysis are indicated in Table 1. The infection of the plantlets with the foliar pathogen Botrytis cinerea produced 132 differential spots whereas more than 220 spots were noted as differential when Trichoderma spp. were exposed to the plant and Rhizoctonia solani or Pythium ultimum, indicating that these soilborne phytopathogens induce major changes in the proteome of $T$. harzianum T34 interacting with the plant. The differential spots between the two-way (Trichoderma spp.-plant) and three-way (Trichoderma spp.-plant-pathogen) interaction condition were identified by mass spectroscopy (MS) and in silico analysis. Interesting homologies were found with the following type of proteins: i) hydrolases and other enzymes such as cellulases, chitin synthases, glucosidases, trehalases, and pro-
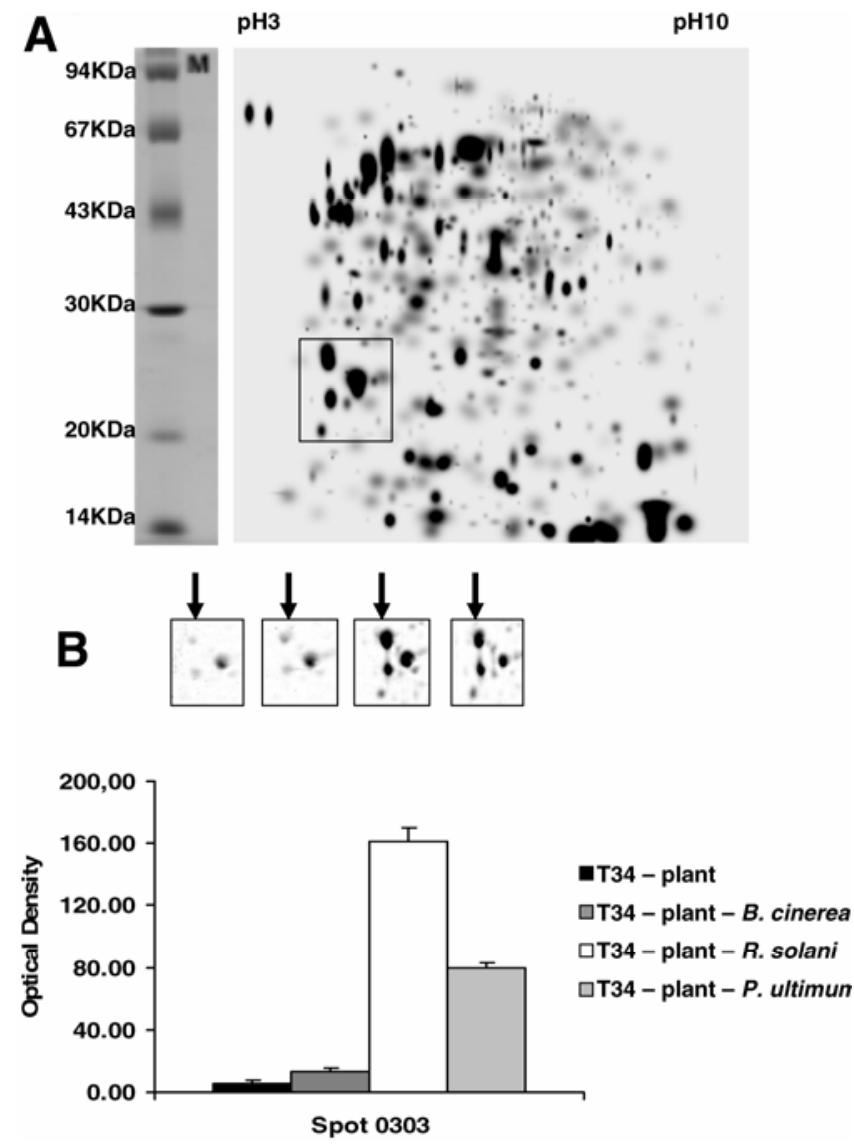

Fig. 1. Analysis of the intracellular proteome of Trichoderma harzianum T34 grown on water agar plates in the presence of plants (tomato plantlets) and three different phytopathogens (Botrytis cinerea, Rhizoctonia solani, or Pythium ultimum). A, Proteomic map. Two-dimensional gel of intracellular proteins extracted from T. harzianum T34 grown in the presence of tomato plantlets and $R$. solani. B, Differential intensity levels of spot 0303 . Spot intensity changes are shown by the enlarged gel regions (picture insets) placed over the corresponding relative intensity (histogram). teases; ii) stress-related proteins; iii) a hydrophobin; iv) an $\mathrm{ABC}$ transporter; v) transcription factors and regulators, such as IME4 and WD40; and vi) proteins involved in basic metabolism and various cellular processes, such as cyclophilins, kinases, phosphatases, a phosphoesterase, a 14.3.3 family protein, a glycosil hydrolase, a phosphocholine cytidyltransferase, a leucine-rich protein, a GTP cyclohydrolase, a cloacin-like protein, a septin, a glyceraldehyde-3-phosphate dehydrogenase, and so on.

The intensity of the spot 0303 was strongly upregulated in the presence of $P$. ultimum (13-fold) and R. solani (27-fold) and less in the presence of $B$. cinerea. MS and in silico analysis of this spot showed a match with an endoPG B of Aspergillus niger (gi|6911545). The subsequent Mascot analysis related the spot 0303 to the expressed sequence tag (EST) L15T34P120R10663 (hereafter, EST 10663) from a T. harzianum T34 EST database (Vizcaíno et al. 2006) generated in the functional genomics TrichoEST project (Rey et al. 2004).

\section{Isolation of Thpg1.}

The spot 0303-related EST 10663 was used as a probe to screen a lambda genomic DNA library (L01). A positive phage was isolated, and a 2,199-bp fragment contained the complete sequence of the Thpgl gene: 1,387 bp, with an open reading frame (ORF) of 1,143 bp and four introns of 54 to $74 \mathrm{bp}$; plus 812 bp of the promoter region. Two oligonucleotides were designed using this genomic sequence for amplifying a 1,143-bp fragment corresponding to the full-length cDNA from library phages by polymerase chain reaction (PCR).

The ORF of Thpgl encodes a protein of 380 amino acids with a theoretical molecular mass of $38.3 \mathrm{kDa}$ and an isoelectric point of 5.02. An analysis of the primary structure of ThPG1 revealed the presence of a putative signal peptide of 21 amino acids and the conserved glycosyl hydrolases family 28 domain related to its catalytic mechanism. The analysis of the Thpg1 promoter region revealed up to six MCM1 motifs involved in the control of cell cycle, CW structure, and metabolism (Kuo and Grayhack 1994).

Southern analysis was carried out in order to analyze the number of Thpg1 copies in the genome of T. harzianum T34, as well as to explore the presence of homologs of this gene in the other Trichoderma spp.: T. asperellum, T. atroviride, $T$. harzianum, T. virens, and T. longibrachiatum (Supplementary Fig. S1). Two and one hybridizing bands were detected with BamHI-digested (one restriction site inside the probe) or XbaIdigested (no restriction sites) genomic DNA of $T$. harzianum T34, respectively, indicating that Thpgl is present as a single copy. Homologous genes were identified in the genomes of all the Trichoderma strains investigated.

\section{Phylogenetic analysis.}

A neighbor-joining (NJ) tree (Fig. 2) was obtained after an alignment of the Thpgl gene with 10 other GenBank-retrieved

Table 1. Changes occurring in the proteome of Trichoderma harzianum T34 during a three-way interaction: T34-tomato (Tom)-Botrytis cinerea (Bot), Rhizoctonia solani (Rhi), or Pythium ultimum (Pyt) ${ }^{\mathrm{a}}$

\begin{tabular}{lccccc}
\hline Condition & Total $^{\mathbf{b}}$ & On $^{\mathbf{c}}$ & Off $^{\mathbf{c}}$ & $\mathbf{U p}^{\mathbf{d}}$ & Down $^{\mathbf{d}}$ \\
\hline T34-Tom-Bot & 132 & 28 & 32 & 46 & 26 \\
T34-Tom-Rhi & 227 & 81 & 24 & 105 & 17 \\
T34-Tom-Pyt & 222 & 82 & 29 & 101 & 10 \\
\hline
\end{tabular}

a The combination T34-tomato was used as control.

b Total number of differential spots.

${ }^{c}$ Number of spots present in T34-tomato condition compared with T34tomato-pathogen (On) or vice versa (Off).

${ }^{\mathrm{d}}$ Number of spots whose intensity in T34-tomato condition increased (Up) or decreased (Down) at least twofold compared with T34-tomato-pathogen. 
sequences, representing genes encoding endo- and exoPG from five Ascomycetes as well as from one Oomycete and one plant, and 11 sequences obtained from the three Trichoderma genomes available online. Two independent clades containing endo- or exoPG could be identified. Ascomycete endoPG formed a major subclade, separated from Oomycete and plant endoPG, as supported by a bootstrap value of $93 \%$. Within the Ascomycete endoPG clade, several subclades, supported by high bootstrap values, were observed. The Thpgl sequence formed a $100 \%$-supported subclade with hypothetical endoPGencoding genes of T. virens, T. atroviride, and T. reesei.

\section{Expression studies.}

The expression of the Thpgl gene was analyzed by Northern blot under a simulated in vitro plant-T. harzianum interaction condition. Total RNA was isolated from strain T34 cultured in minimal medium (MM) liquid medium (control) or $\mathrm{MM}$ amended with different plant $\mathrm{CW}$ polymers or tomato plantlets and harvested at different time points (Fig. 3). A marked hybridization signal with a Thpgl probe was observed when the fungus was cultured for $24 \mathrm{~h}$ in the medium containing $0.5 \%$ pectin or $0.5 \%$ polygalacturonic acid (PGA). A less-marked signal was observed in 24-h-old mycelia grown together with tomato plantlets or in the presence of $0.1 \%$ pectin and 8 -h-old mycelia in the presence of $0.5 \%$ pectin. No Thpgl gene expression was detected in the control condition (MM medium with glucose and nitrogen starvation).

In vivo Thpgl expression analysis was performed by realtime PCR using a three-component system, in which T. harzianum T34 was applied together with a phytopathogen in the rhizosphere of tomato plants. Total RNA from $T$. harzianum T34 grown for $24 \mathrm{~h}$ in plates hosting the three-component (T34-tomato-P. ultimum), two-component (T34-tomato), or T34 (control condition) system was used. Compared with the control, higher transcript levels of Thpgl were detected in the presence of $P$. ultimum (Fig. 4).

Thpgl expression was investigated using real-time PCR after growing strain T34 for 24 or $48 \mathrm{~h}$ in concentrated (10- or 18fold) tomato- $R$. solani co-culture filtrates. No gene expression was detected under the different conditions assayed.

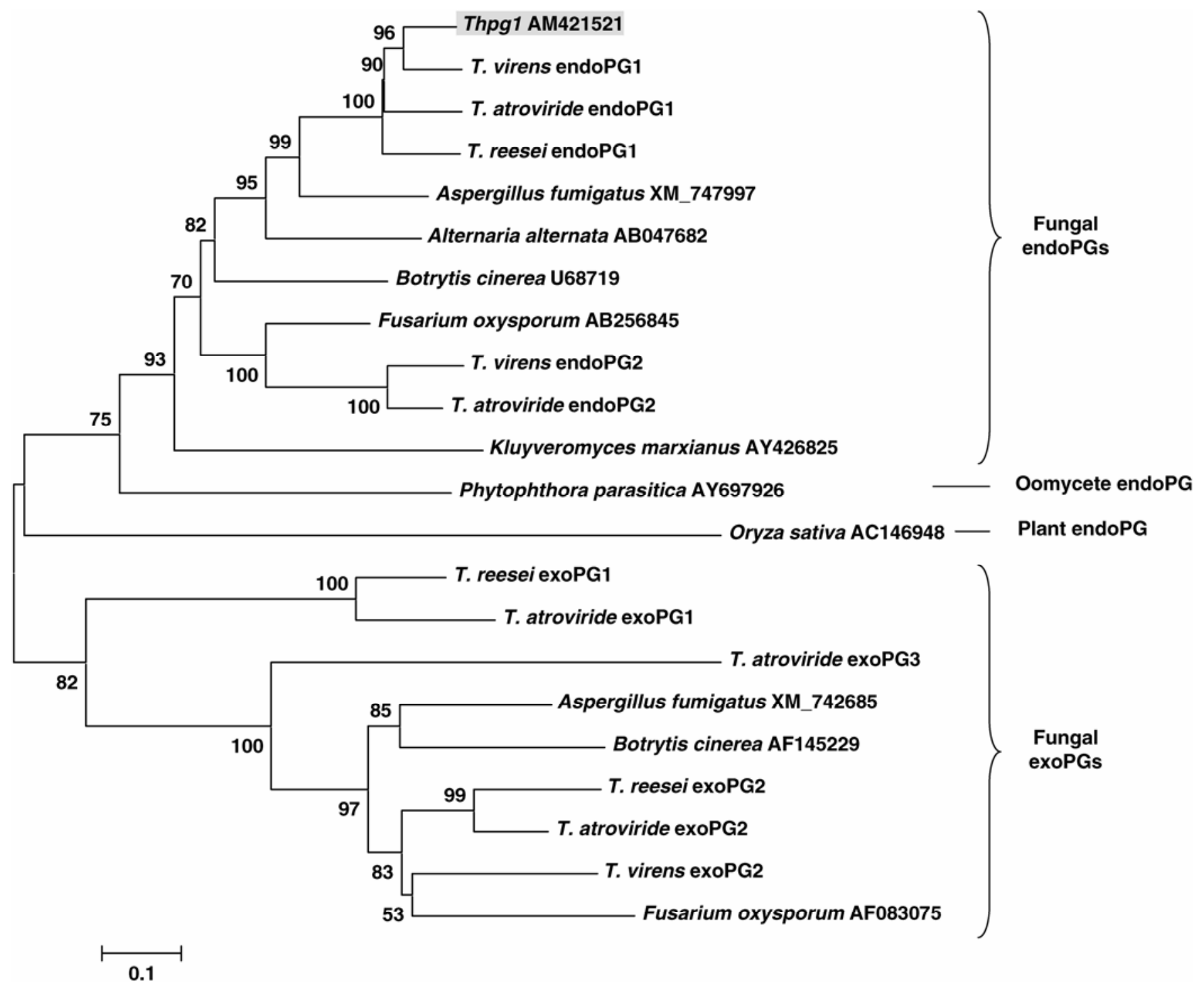

Fig. 2. Neighbor-joining (NJ) tree of Thpg1 from Trichoderma harzianum T34 and another 21 polygalacturonase (PG) and hypothetical PG genes. Nucleotide sequences were obtained from T. reesei (protein ID: 103049 [endoPG1], 70186 [exoPG1], and 112140 [exoPG2]), T. virens (protein ID: 51095 [endoPG1], 58787 [endoPG2], and 48906 [exoPG2]), T. atroviride (protein ID: 83873 [endoPG1], 28947 [endoPG2], 86622 [exoPG1], 87581 [exoPG2], and 55045 [exoPG3]), Aspergillus fumigatus, Alternaria alternata, Botrytis cinerea, Fusarium oxysporum, Kluyveromyces marxianus, Phytophthora parasitica, and Oryza sativa. Sequences from Trichoderma spp. are available online from the DOE Joint Genome Institute. Sequences are indicated using their GenBank accession numbers. Bar represents ten substitutions per 100 nucleotides. 


\section{PG activity.}

PG activity was determined in supernatants from T. harzianum T34 cultures after 4,8 , and $24 \mathrm{~h}$ of incubation in the Thpgl expression test conditions described above, as well as after $36 \mathrm{~h}$ in $0.5 \%$ pectin and with $0.5 \%$ PGA used as the substrate. A value of 7.40 enzyme units per milligram of protein was detected in the 24 -h-old culture supernatant ( $0.5 \%$ pectin), decreasing to $3.39 \mathrm{U} / \mathrm{mg}$ of protein after $36 \mathrm{~h}$ of growth. In the 24-h-old culture supernatant obtained in the presence of $0.1 \%$ pectin, $0.5 \%$ PGA, or $1 \%$ tomato plant, where a lower transcript signal compared with the $0.5 \%$ pectin condition was observed (Fig. 3A), PG activity was detectable only if the sample was concentrated five- to ninefold, obtaining values of 1.37 , 1.15 , and $0.33 \mathrm{U} / \mathrm{mg}$ of protein, respectively. In the 8 -h-old culture supernatant with $0.1 \%$ pectin, $\mathrm{PG}$ activity could be detected only after a 15 -fold concentration.

\section{PG inhibition by PGIP.}

The sensitivity of ThPG1 to different PG inhibitor proteins (PGIP), two from Arabidopsis thaliana (AtPGIP1 and AtPGIP2) and two from Phaseolus vulgaris (PvPGIP1 and PvPGIP2), was assayed following the method described by Ferrari and associates (2003). Arabidopsis PGIP were unable to inhibit the ThPG1 activity. By contrast, an inhibitory effect of Phaseolus PGIP was observed: approximately $50 \mathrm{ng}$ of PvPGIP2 and $130 \mathrm{ng}$ of PvPGIP1 was necessary to inhibit 1 agarose plate unit of ThPG1.

\section{Silencing of Thpg1 gene and characterization of transformants.}

The function of Thpgl in T. harzianum T34 was studied by gene silencing. The method used to silence this gene was based on the generation of an intron containing self-complementary "hairpin" RNAs (ihpRNA). T. harzianum T34 was transformed with the pSIL-PG1 construct (Supplementary Fig. S2). From the regenerated protoplasts, we selected 14 transformants growing on tryptone soy agar medium amended with phleomycin at $200 \mu \mathrm{g} / \mathrm{ml}$. Single-spore cultures were isolated from transformants and they kept their resistance to phleomycin.

The integration of pSIL-PG1 was determined by PCR using the oligonucleotides IntF and Tcbh2 as the primers. The presence of a 1,218-bp amplification fragment was confirmed for all 14 transformants. Southern analysis was performed on T34 and four Thpgl-silenced strains (ePG4, ePG5, ePG6, and ePG8) by digesting gDNAs with EcoRI (no restriction site in Thpg1) and using Thpgl cDNA as a probe. The wild-type strain showed only one band of approximately $13 \mathrm{~kb}$, whereas, for the transformants ePG4, ePG5, ePG6, and ePG8, additional insertions of the transformation cassette were detected (Supplementary Fig. S3). In particular, ePG4 and ePG8 contained four and three insertions, respectively.

To analyze the effect of Thpgl silencing on PG activity, supernatants for wild-type and transformant strains were obtained from 24 -h-old cultures on MM plus $0.5 \%$ pectin. $\mathrm{PG}$ activity values for the different strains, obtained by using $0.2 \%$

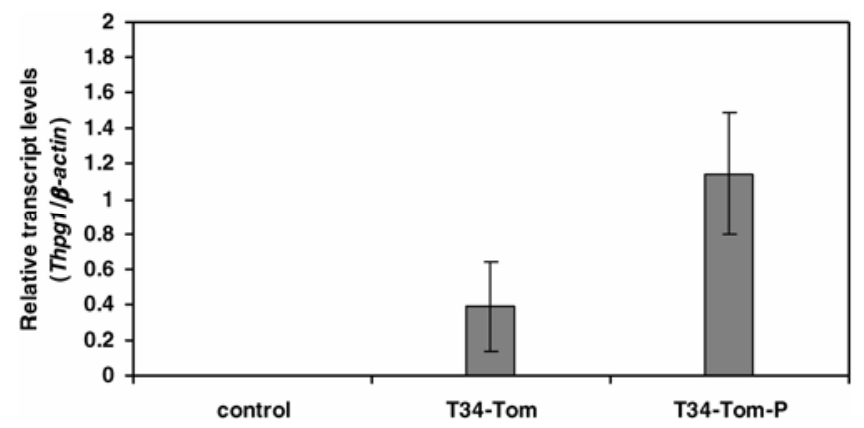

Fig. 4. Quantification of the Thpgl transcripts in Trichoderma harzianum T34 mycelia by real-time polymerase chain reaction. The fungus was grown on minimal medium (control) or in the presence of tomato (T34Tom) or tomato and Pythium ultimum (T34-Tom-P), as described by Marra and associates (2006).

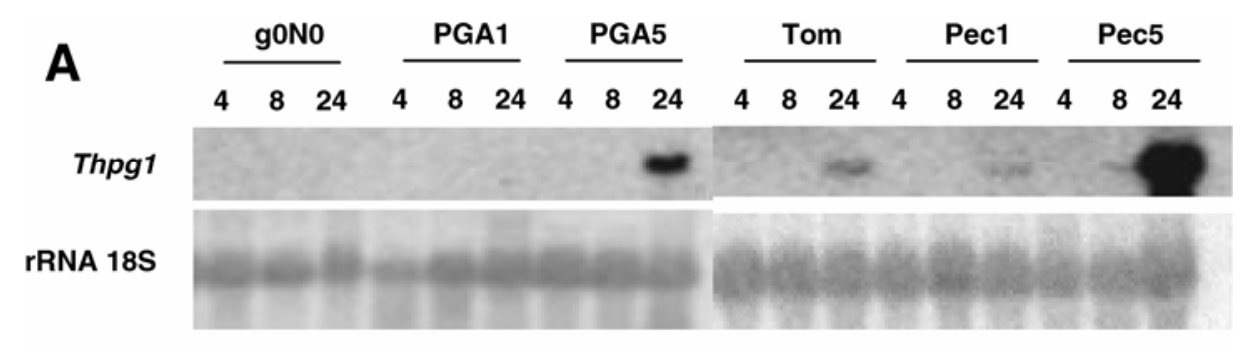

B

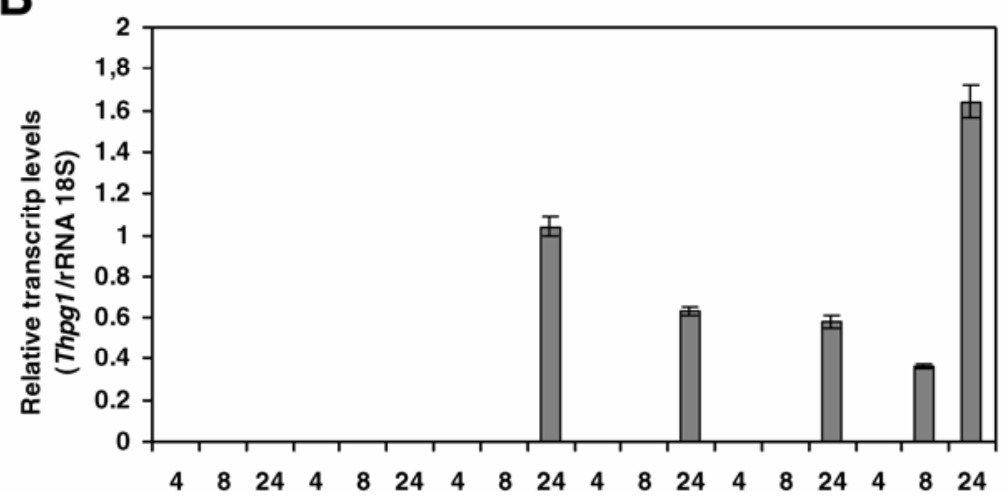

Fig. 3. In vitro expression analysis of Thpg1 gene of Trichoderma harzianum T34. A, Northern blot experiments were carried out with total RNA ( $20 \mu \mathrm{g}$ ) extracted from mycelia of T. harzianum T34 grown on minimal medium (Penttilä et al. 1987) containing no glucose but one of the following carbon source: 0.1 or $0.5 \%$ polygalacturonic acid (PGA1 or PGA5), 0.1 or $0.5 \%$ pectin (Pec1 or Pec5), or 1\% tomato plants (Tom). A glucose and nitrogen starvation condition (g0N0) served as the control. The Thpgl open reading frame and 18S rRNA gene from T. harzianum T34 were used as probes. B, Relative transcript levels of Thpgl gene versus rRNA 18S. 
PGA as substrate, are shown in Figure 5A. All four T. harzianum transformants presented values of PG activity lower than the wild-type T34 strain. Particularly, ePG5 exhibited a decrease of $87.0 \%$ in the PG activity relative to T34. The PG activity of ePG4, ePG6, and ePG8 was reduced, compared with the wild type, 47,83 , and $68 \%$, respectively.

We compared the expression level of Thpgl in three of the Thpg1-silenced transformants (ePG5, ePG6, and ePG8) and the wild-type strain by amplifying a fragment of $425 \mathrm{bp}$ not used for the silencing using primers endop-1 and endop-5. Total RNA from T. harzianum T34 and transformants was extracted from 24-h-old mycelia grown on MM amended with $0.5 \%$ pectin. Compared with the wild-type strain (ratio 1 ), the ratio values were lower in ePG5, ePG6, and ePG8 (0.006, 0.010 , and 0.071, respectively). Therefore, Thpgl expression was reduced by 167-, 100-, and 14-fold, respectively, for the three silenced transformants.

In order to investigate the role of Thpgl on pectin assimilation in T. harzianum, silenced mutant ePG5 and T34 wild
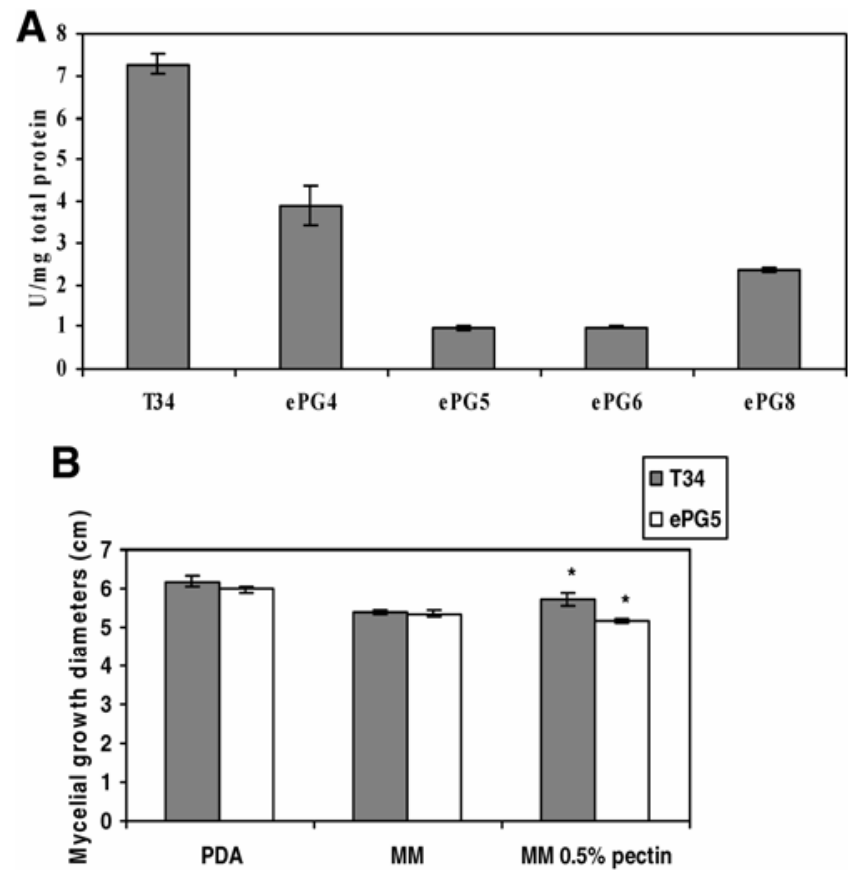

Fig. 5. Analysis of the Trichoderma harzianum T34 Thpg1-silenced transformants. A, Polygalacturonase (PG) activity measured in supernatants from T. harzianum T34 and silenced transformants ePG4, ePG5, ePG6, and $\mathrm{ePG} 8$ after $24 \mathrm{~h}$ of growth in minimal medium (MM) supplemented with $0.5 \%$ pectin. The release of reducing ends from polygalacturonic acid was measured, and results expressed as specific activity (U/mg of total protein). B, Colony diameter $(\mathrm{cm})$ of $T$. harzianum $\mathrm{T} 34$ and the silenced strain ePG5 on potato dextrose agar (PDA), solid MM (Penttilä et al. 1987), and solid MM supplemented with $0.5 \%$ pectin. Values are means of three replicates with the corresponding standard deviations. Bars marked with asterisk differ significantly (Fisher's test). types were grown on potato dextrose agar (PDA) and MM medium (control conditions) and MM medium supplemented with $0.5 \%$ pectin (Fig. 5B).

The two control treatments produced comparable colony sizes, and strain ePG5 showed a statistically significant reduced growth on the pectin-containing medium compared with the wild type.

The role of Thpg1 in plant rhizosphere colonization was evaluated on tomato roots by real-time PCR using the silenced transformant ePG5 and T. harzianum T34. The amount of ePG5 DNA obtained from tomato roots was approximately eightfold lower than that of the wild type (Table 2).

The plant response to Thpgl was analyzed in the T. harzianum-A. thaliana interaction using Arabidopsis microarrays. The comparison of the plant T34-treated versus the plant ePG5-treated transcriptomes showed that just 10 Arabidopsis genes, with a false discovery rate (FDR) of 0.33 , had a reduced expression level, between 11.9- and 1.8-fold, in the presence of the silenced transformant (Table 3). They are i) GRP19 and $G R P 20$, which encode CW structural proteins and may help to repair the CW (Mousavi and Hotta 2005); ii) XTR7 and XTH9, which hydrolize plant xyloglucans and have been involved in Medicago trunculata root colonization by Glomus versiforme (Maldonado-Mendoza et al. 2005); iii) GRP and XTH, which were upregulated in Pinus microarrays after mycorrhizal colonization (Heller et al. 2008); iv) chalcone synthase (CHS), which was triggered by OGA and has been related to defense response (Shaw et al. 2006); v) a lipid transfer protein (LTP) gene belonging to a family involved in plant cell physiology and defense (Carvalho and Moreira 2007); and vi) a cysteine proteinase inhibitor gene elicited by $\mathrm{CW}$ oligomers and involved in defensive responses against insects and pathogens (Belenghi et al. 2003; Hermosa et al. 2006). The GRP19, ATA20, XTR7, and CHS gene expression was validated by Northern blot (data not shown). For all these Arabidopsis genes, a lower transcript level was observed $24 \mathrm{~h}$ after inocula-

Table 3. Differential expression of 10 Arabidopsis genes during the interaction with the wild-type Trichoderma harzianum strain T34 and the endopolygalacturonase-silenced mutant ePG5

\begin{tabular}{lcr}
\hline Gene name and description & $\begin{array}{c}\text { Probe set } \\
\text { ID }\end{array}$ & Ratio $^{\mathbf{a}}$ \\
\hline Glycine-rich protein, GRP19 & 250610_at & 11,929 \\
Anther development protein, ATA20 & 258392 at & 6,656 \\
Lipid transfer protein, LTP & 256381 at & 8,400 \\
Xyloglucosyl transferase, $X T R 7$ & 245325 at & 3,747 \\
60S ribosomal protein, $R P P 2 C$ & 256597 at & 2,877 \\
Glycine-rich protein, GRP20 & 250639 at & 2,386 \\
Cysteine proteinase inhibitor B & 265672_at & 4,089 \\
Chalcone synthase, $C H S$ & 250207 at & 1,779 \\
Xyloglucan endotransglucosylase, XTH9 & 255433_at & 2,674 \\
Extracellular lipase 6, EXL6 & 262675_at & 2,892
\end{tabular}

${ }^{a}$ Indicated ratio value represents the fold change in gene expression during the interaction with T34 compared with ePG5 $24 \mathrm{~h}$ after inoculation with fungi.

Table 2. Colonization of tomato roots by Trichoderma harzianum wild-type T34 and the Thpg1-silenced transformant ePG5 ${ }^{\mathrm{a}}$

\begin{tabular}{|c|c|c|c|c|c|c|c|c|c|}
\hline \multirow[b]{2}{*}{ Condition } & \multicolumn{4}{|c|}{$\beta$-Tubulin } & \multicolumn{4}{|c|}{ Chalcone synthase } & \multirow[b]{2}{*}{ Ratio $^{d}$} \\
\hline & $\mathbf{C t}$ & SD & Qty $^{\mathbf{b}}$ & SD & $\mathrm{Ct}$ & SD & Qty $^{\mathrm{c}}$ & SD & \\
\hline Tom-T34 & 22.39 & 0.164 & 9.71 & 1.119 & 25.79 & 0.174 & 10.73 & 1.274 & 0.905 \\
\hline Tom-ePG5 & 24.49 & 0.072 & 2.27 & 0.114 & 24.89 & 0.101 & 20.27 & 1.484 & 0.112 \\
\hline
\end{tabular}

${ }^{a}$ Fungal DNA present on the tomato roots (Tom) $24 \mathrm{~h}$ after the inoculation was quantified by real-time polymerase chain reaction. Three replicates were made of each sample. $\mathrm{Ct}=$ threshold cycle and $\mathrm{SD}=$ standard deviation.

${ }^{\mathrm{b}}$ Quantity of fungal DNA (ng) referred to $\beta$-tubulin gene in $1 \mu \mathrm{l}$ of total DNA.

${ }^{c}$ Quantity of plant DNA (ng) referred to chalcone synthase gene in $1 \mu$ l of total DNA.

${ }^{\mathrm{d}}$ Proportion of fungal DNA versus plant DNA per $1 \mu \mathrm{l}$ of total DNA. 
tion with the silenced strain ePG5 compared with strain T34, which was consistent with the microarray data.

\section{Biocontrol assay in tomato.}

Results obtained in B. cinerea-infected tomato assays with strains T34 and ePG5 showed that Thpgl silencing did not affect the biocontrol activity of T. harzianum (Fig. 6; Supplementary Fig. S4). Severity of leaf necrotic lesions (NSL) produced by $B$. cinerea B05.10 was measured in tomato plants previously seed-coated with an aqueous solution (control) or treated with conidia of T34 or ePG5. The highest sizes of necrotic lesions and tissue maceration were observed in the control and no statistically significant differences were observed among the necrotic lesion sizes observed in the T34 and ePG5 treatments. However, leaf necrotic lesions caused by $B$. cinerea were slightly smaller in plants pretreated with ePG5.

\section{DISCUSSION}

The present study provides a contribution to the understanding of the complex in vivo interaction occurring in the plant rhizosphere between a mycoparasitic biocontrol agent and its hosts. It reports the isolation and characterization, by proteomic, genomic, and transcriptomic methods, of a novel Trichoderma gene coding for a plant $\mathrm{CW}$-degrading enzyme.

Trichoderma proteome changes during antagonist-plantpathogen cross-talk were investigated. Several proteins differentially regulated by the presence of the pathogen in the threeway combination and that could be used by $T$. harzianum to colonize the roots-for instance, by partially degrading the plant CW (i.e., glucanases, proteases, cellulases, and so on)were found (data not shown). Spot 0303, markedly increased in the presence of the soilborne pathogens $R$. solani and Pythium ultimum, was related to an EST clone (10663) as found by using a modified Mascot analysis (Suárez et al. 2005) and a database of Trichoderma EST constructed during the TrichoEST project (Rey et al. 2004), and showed a high identity with endoPG. Precisely, this clone was obtained from the unique L15 library constructed after exposing the fungus to plant $\mathrm{CW}$ polymers.

The endo- and exoPG NJ tree separation was in agreement with what was reported by other authors (Götesson et al. 2002). All other fungal endoPG genes, including those from Aspergillus, Sclerotinia, and Fusarium spp., have displayed high variability in intron number and sequence size (Annis and Goodwin 1997). Instead, the Trichoderma endoPG genes

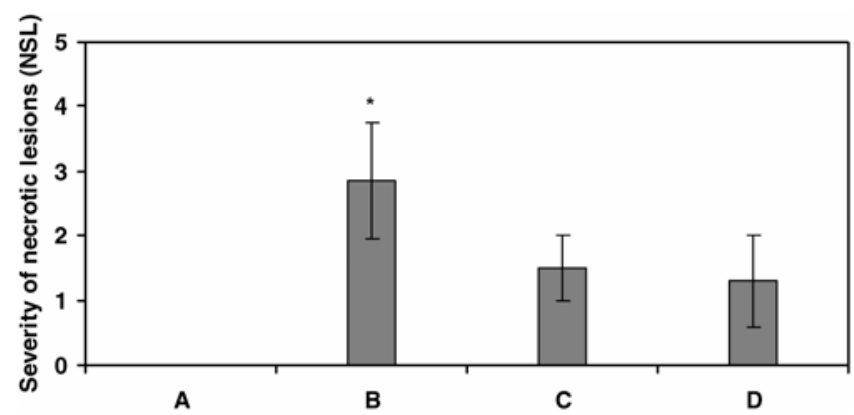

Fig. 6. Severity of necrotic lesions (NSL) observed in tomato leaves after Trichoderma harzianum seed treatment and Botrytis cinerea B05.10 conidia infection. Untreated and uninfected control (A), untreated seed and $B$. cinerea-infected leaves (B), T. harzianum T34-treated seed and $B$. cinerea-infected leaves (C), and T. harzianum ePG5-treated seed and $B$. cinerea-infected leaves (D). NSL data were registered 4 days after $B$. cinerea infection. The standard deviation bars were obtained from at least two different experiments, with eight replicates of infection spots. Asterisk represents statistically significant differences (Fisher's test). seemed to cluster in only two independent subclades made of members with relatively common features. The one that contained Thpgl included genes all having four introns and a size of approximately $1,300 \mathrm{bp}$ while the other, which included endoPG of $T$. virens and T. atroviride, consisted of genes with one intron and of approximately $1,100 \mathrm{bp}$ in size. These data suggest the presence of different endo- and exoPG families also in Trichoderma spp.

An in silico analysis of $812 \mathrm{bp}$ of the promoter region of Thpgl showed putative motifs related to development control (Adrianopoulos and Timberlake 1994), saprophytic growth (Herbert et al. 2002), pectinolytic gene activation (de Vries et al. 2002), carbon metabolism (Zeilinger et al. 2001), and mycoparasitism (Cortes et al. 1998). Results obtained after analyzing the Thpgl transcript levels in T. harzianum T34 under different in vitro growth conditions show that plant material and polymers trigger expression of this gene. Recently, D'Ovidio and coworkers (2004a) indicated that regulation of endoPG genes is generally conditioned by the available carbon source. We observed the same phenomenon in T. harzianum, where Thpgl expression could be increased by adding more pectin or PGA in the medium (from 0.1 to $0.5 \%$ ) (Fig. 3A). Except for $0.5 \%$ pectin, expression data are not very consistent with PG activity. The delay between the timing of transcript expression and PG secretion as well as the contribution of others PG isoforms to total PG activity may also be taken into account. The possible involvement of Thpgl in mycoparasitism is unclear. A mycoparasitism-related motif (MYC) was observed in the promoter but no upregulation of the gene was detected by Northern analysis of mycelia grown in the presence of $1 \%$ B. cinerea, $P$. ultimum, or $R$. solani $\mathrm{CW}$ (data not shown).

It has been demonstrated that the presence or absence and location of some specific amino acids in the sequence of fungal endoPG is critical to PGIP binding (Raiola et al. 2008). Similarly to endoPG from Fusarium moniliforme and Aspergillus niger (De Lorenzo and Ferrari 2002), the T. harzianum ThPG1 was unaffected by PGIP of Arabidopsis thaliana and inhibited by PvPGIP1 and PvPGIP2 of Phaseolus vulgaris. However, a much higher amount of PvPGIP2 (130 ng) was needed to inhibit the activity of the biocontrol agent ThPG1 compared with endoPG from phytopathogenic fungi such as Aspergillus niger, F. moniliforme, Colletotrichum acutatum, or B. cinerea (D'Ovidio et al. 2004b). This is in agreement with the hypothesis that there is a relatively high degree of specificity in endoPG-PGIP interactions (De Lorenzo and Ferrari 2002; Kemp et al. 2004).

Northern and proteomic results showed that in vitro Thpgl expression and in vivo ThPG1 intracellular production were low during the two-player interaction (T34-tomato). However, a marked increase of ThPG1 amount was detected in the proteomes from the in vivo three-player interactions T34-tomato$R$. solani and T34-tomato-Pythium ultimum. This result was subsequently confirmed by real-time PCR (Fig. 4), which demonstrated that the presence of a pathogen in the system triggers the expression of Thpgl. In order to analyze whether the presence of oligomers released by the pathogens could trigger a higher expression of Thpgl gene in a three-component system, strain T34 was grown in tomato- $R$. solani co-culture filtrates. Although different incubation times ( 24 and $48 \mathrm{~h}$ ) and filtrates of different ages ( $48 \mathrm{~h}, 72 \mathrm{~h}$, and 1 week) and concentrations (10- and 18-fold) were assayed, no Thpgl expression was detected. Probably, the amount of oligomers present in the filtrates tested was unable to trigger Thpgl gene expression. Eventually, we were not able to reproduce in vitro the many factors that regulate the multiplayer systems that we are investigating.

The gene-silencing strategy used in this work was successfully applied in Trichoderma spp. to analyze the function of 
the terpene-related genes ergl and $h m g R$ (Cardoza et al. 2006, 2007). We found no correlation between the number of pSILPG1 copies inserted and the level of PG activity in the best Thpg 1-inducing conditions ( $24 \mathrm{~h}$ culturing on MM plus $0.5 \%$ pectin). In fact, the lowest PG activity reduction compared with the wild type occurred in those transformants, ePG4 and ePG8, with the highest number of transformation-cassetteinserted copies. The same lack of correlation was also reported when genes encoding chitinase and heat shock protein were overexpressed in Trichoderma spp. (Limón et al. 1999; Montero-Barrientos et al. 2007). Regardless, we confirmed by real-time PCR that the reduction of Thpgl expression and PG activity were related, and selected for the phenotype study a strongly silenced mutant (minus 167-fold Thpgl expression and a residual enzymatic activity of only $13 \%$ ).

The mutant ePG5 generally showed a growth rate similar to that of the wild type on MM and PDA media, and was still able to use pectin as the only carbon source. This was probably due to the residual ThPG1 activity derived from the incomplete silencing of the gene or the presence of other endo- and exoPG in strain T34. A correlation between PG activity and growth reduction in pectin-based media was reported in double endo- and exoPG Cochliobolus carbonum mutants (ScottCraig et al. 1998), and in an endo-PG mutant of Alternaria citri (Isshiki et al. 2001). On the contrary, an endo-PG mutant of $C$. carbonum with a $30 \%$ reduction in PG activity grew as well as the wild type in the presence of pectin as the sole carbon source (Scott-Craig et al. 1990).

A comparison of tomato root colonization by strains T34 and ePG5 showed that Thpgl is involved in this process. In fact, the amount of ePG5 DNA obtained from tomato roots was eightfold less than that of the wild type. This result, which is in agreement with the data from growth assays on pectin, indicates that ThPG1 supports rhizosphere colonization by the biocontrol fungus and pectin degradation may be an important step in the beneficial Trichoderma-plant interaction. Accordingly, endoPG disruptants of $A$. citri showed a reduced colonization ability of citrus fruit tissues (Isshiki et al. 2003).

Efficient root colonization is considered important for the well-known Trichoderma spp. beneficial effect on the plant (Brotman et al. 2008; Harman et al. 2004; Yedidia et al. 1999). Several authors have reported that OGA generated by PG enzyme activity can elicit plant defense responses (Casasoli et al. 2008; Poinssot et al. 2003). Using Arabidopsis microarrays, we have investigated the possibility that Thpgl may be involved in the often observed ability of T. harzianum, as well as other Trichoderma spp., to activate or prime plant defense mechanisms (Djonovic et al. 2007; Harman et al. 2004; van Wees et al. 2008). This method has permitted an in-depth investigation of rhizobacteria-ISR (Verhagen et al. 2004). We found only 10 plant genes related to $\mathrm{CW}$ metabolism and plant defense, which were downregulated in the presence of ePG5 relative to T34. Of these 10 genes, six (GRP19, GRP20, ATA20, XTR7, XTH9, and EXLO) encode proteins involved in CW construction or degradation and in plant defense responses. Others, such as CHS, LTP, or a protease inhibitor gene, are involved in plant defense. The downregulation of ISR-linked genes observed in Arabidopsis roots colonized with the Thpgl-silenced transformant could anticipate a possible reduction in the protection against plant pathogens. However, in vivo biocontrol assays showed that $B$. cinerea leaf necrotic lesions were slightly smaller in plants colonized by ePG5, although no statistically significant differences were observed between T34 and ePG5 treatments.

The data set presented in this article supports the hypothesis that activity of ThPG1 on the plant $\mathrm{CW}$ is required for an efficient root colonization by $T$. harzianum. However, further in vivo assays are needed to understand the Thpgl role in the biocontrol effect mediated by the activation of the plant ISR mechanism in other pathosystems.

\section{MATERIALS AND METHODS}

\section{Fungal and plant material.}

T. harzianum T34 (CECT 2413; Spanish Type Culture Collection, Valencia, Spain), T. atroviride T11 (NBT11; Newbiotechnic S.A., Seville, Spain), T. harzianum T22, T. asperellum T25 (NBT25), T. longibrachiatum T52 (NBT52), and T. virens T59 (NBT59) were used in this study. Strain 26 of B. cinerea, isolated from tobacco, and strain 19 of $R$. solani and strain 8 of $P$. ultimum, isolated from tomato, were used as sources of fungal CW. Strain B05.10 of B. cinerea was used as a pathogenic fungus in biocontrol assays in tomato. All microorganisms were maintained on PDA (Difco Becton Dickinson, Sparks, MD, U.S.A.).

Arabidopsis thaliana Col-0 ecotype and Lycopersicon esculentum cv. Marmande plants were used. Sterilized seed were sowed in tubes containing Murashige and Skoog medium (Murashige and Skoog 1962) supplemented with 1\% (wt/vol) sucrose and $1 \%(\mathrm{wt} / \mathrm{vol})$ agar, $\mathrm{pH}$ 5.7. They were placed in a growth chamber at $22^{\circ} \mathrm{C}$ and $40 \%$ humidity with a light-anddark photoperiod of 16 and h, respectively, at 80 to $100 \mu \mathrm{E}$ $\mathrm{m}^{-2} \mathrm{~s}^{-1}$.

\section{Culture conditions.}

Trichoderma-plant-pathogen interaction was simulated on WA plates as previously described (Marra et al. 2006) by using 15-day-old tomato plants and separating the three components (plant, Trichoderma spp., and pathogen) with a sterile cellophane membrane.

For Southern analysis, Trichoderma strains were cultivated in shake flasks $(150 \mathrm{rpm})$ in potato dextrose broth (PDB, Difco Becton Dickinson) at $25^{\circ} \mathrm{C}$ for $48 \mathrm{~h}$.

For in vitro expression studies, T. harzianum T34 mycelia were obtained following a two-step liquid culture procedure (Vizcaíno et al. 2006). First, the fungus was grown in MM (Penttilä et al. 1987) containing $2 \%$ glucose at $28^{\circ} \mathrm{C}$ for $36 \mathrm{~h}$. The fungal biomass was harvested and transferred to MM containing no glucose but one of the following carbon sources: 0.1 or $0.5 \%$ PGA, 0.1 or $0.5 \%$ pectin, or $1 \%$ tomato plants. A glucose and nitrogen starvation (g0N0) served as the control. Cultures were maintained at $25^{\circ} \mathrm{C}$ on a rotary shaker at $150 \mathrm{rpm}$ for 4,8 , or $24 \mathrm{~h}$. Nitrogen starvation conditions included a 100 -fold decrease in the concentration of ammonium sulfate in the medium ( $50 \mathrm{mg} / \mathrm{liter}$ ). Tomato plant material was obtained by removing the roots of 8 -week-old plants and subsequently freezing and powdering the aerial part.

For T34 expression studies in tomato- $R$. solani co-culture filtrates, mycelium of T34 previously obtained from a liquid PDB culture was incubated for 24 and $48 \mathrm{~h}$ in $R$. solanitomato co-culture filtrates. For this, MM supplemented with $2 \%$ of 15-day-old tomato plantlets was inoculated with $1 \% R$. solani mycelium and cultured at $25^{\circ} \mathrm{C}$ and $120 \mathrm{rpm}$ for 12 days. Supernatants were harvested by filtration and concentrated 10- and 18-fold using a speed-vacuum system.

For in vivo expression studies, T. harzianum T34 mycelia were obtained in the same growth conditions used to simulate the Trichoderma-plant-pathogen interaction described by Marra and associates (2006).

To perform tomato rhizosphere colonization tests, 20-dayold plants were cultured in a 10-ml Erlenmeyer flask containing $8 \mathrm{ml}$ of liquid Murashige and Skoog medium inoculated with $10^{5}$ conidial germlings $\mathrm{ml}^{-1}$ of Trichoderma strain (T34 or ePG5) or $100 \mu \mathrm{l}$ of sterile water (control) in an orbital incubator at $80 \mathrm{rpm}$ and $25^{\circ} \mathrm{C}$. Conidia were obtained from 15 -h-old 
cultures of the strains T34 or ePG5 in PDB (Difco Becton Dickinson), and left to germinate at $25^{\circ} \mathrm{C}$ in $200 \mathrm{ml}$ of PDB medium shaken at $200 \mathrm{rpm}$. After $24 \mathrm{~h}$ of plant-Trichoderma interaction, roots from six plants per treatment were collected, washed with distilled water, frozen, lyophilized, and kept at $80^{\circ} \mathrm{C}$ until total RNA extraction. Three independent tomatoTrichoderma co-culture experiments were carried out.

For the microarray-based experiments, 25-day-old Arabidopsis plants were cultured in the conditions described above for the colonization assays. After $24 \mathrm{~h}$, samples from the aerial part of 10 Trichoderma-colonized plants per each treatment were collected, combined, treated as described above, and used for RNA extraction. Three technical replicates were performed per each treatment.

\section{Cell proteins extraction.}

The protein extraction protocol applied in this work was the one described by Jacobs and associates (2001) with the modifications indicated by Marra and associates (2006).

\section{Isoelectric focusing and 2-DE.}

Isoelectric focusing (IEF) was carried out in a PROTEAN IEF Cell system (Bio-Rad Laboratories Inc., Hercules, CA, U.S.A.) by using $11-\mathrm{cm}$ immobilized-pH-gradient (IPG) strips (Bio-Rad Laboratories Inc.) with a $\mathrm{pH}$ of 3 to 10 (intracellular proteins). IPG, 2-DE, and staining procedure were performed as described by Marra and associates (2006).

Gel images were acquired by a GS-800 Imaging Densitometer (Bio-Rad Laboratories Inc.) and analyzed with the PDQuest software. Image files were recorded by using a red filter (wavelength 595 to $750 \mathrm{~nm}$ ) and a resolution of 36.3 by 36.3 microns. The signal intensity of each spot was determined in pixel units (optical density) from four different two-dimensional gels and normalized to the sum of the intensities of all the spots included in the standard gel. Protein spots were considered to be "differentially produced" if at least a twofold intensity variation was detected when responses to different interaction conditions were compared.

\section{In-gel digestion, matrix-assisted laser desorption-ionization time-of-flight MS, and in silico analysis.}

Protein spots were excised from gels and digested with bovine trypsin as described by Talamo and associates (2003). Each spot was indicated with the standard spot number assigned by PD-Quest software. Tryptic-digested peptides were resuspended in $10 \mu \mathrm{l}$ of a $1 \%$ acetic acid solution and the samples were mixed (1:1) with a matrix of a saturated $\alpha$-cyano-4-hydroxycinnaminic acid solution (acetonitrile at $10 \mathrm{mg} / \mathrm{ml} / 0.2 \%$ trifluoroacetic acid, 70:30] (Sigma-Aldrich, St. Louis). Then, $1 \mu \mathrm{l}$ of the mixture was matrix-assisted laser desorption-ionization time-of-flight analyzed in a mass spectrometer (Applied Biosystem, Foster City, CA, U.S.A.) according to the protocol described by Marra and associates (2006).

Peptide mass fingerprint data were matched to the National Centre of Biotechnology Information nonredundant database entries against proteins from fungal or all species, using the Mascot software (Matrix Science, London). A modified Mascot analysis was also performed by using a Trichoderma EST clones database, built as described by Vizcaíno and associates (2006, 2007), supported by the TrichoEST European Union project (Rey et al. 2004).

\section{Libraries of T. harzianum T34.}

L01 and L15 T. harzianum T34 libraries were used for cloning the Thpgl gene in this study. L01 is a lambda genomic library and was previously described (Lora et al. 1995). L15 is a cDNA library, constructed with RNA obtained after growing
T. harzianum T34 in MM (Penttilä et al. 1987) without glucose but supplemented with $0.1 \%$ PGA, $0.1 \%$ CMC, $0.1 \%$ pectin, and $0.1 \%$ xylan (all from Sigma-Aldrich) for $36 \mathrm{~h}$ at $28^{\circ} \mathrm{C}$ and $160 \mathrm{rpm}$. The mycelium was harvested, total RNA was extracted, mRNA was purified, and the L15 library was constructed in Uni-ZP XR Vector System (Stratagene, La Jolla, CA, U.S.A.) (Vizcaíno et al. 2006).

\section{Molecular cloning.}

Standard molecular techniques were used throughout this work (Sambrook and Russel 2001). The L01 library was screened with a 510-bp PCR fragment, corresponding to the EST 10663, which was labeled by random primers (Roche Applied Science, Mannheim, Germany). Labeling, hybridization, and immunological detection were carried out using a nonradioactive labeling and immunological detection kit and CDP-Star as the chemiluminescent substrate (Roche Applied Science), as previously described (Hermosa et al. 2000). The DNA of a positive phage was isolated and sequenced to obtain the complete Thpgl gene.

\section{PCR procedures.}

The complete cDNA of Thpgl was obtained by PCR using the primers endop-1 (5'-CAT GAC CAA ACT ATC CCT TCT C-3') and endop-2 (5'-CTT AAC AAG TAG CAA CAC TTG G-3') and DNA from phages of L15 cDNA library as template. PCR was carried out for 35 cycles of $1 \mathrm{~min}$ at $94^{\circ} \mathrm{C}, 1.5 \mathrm{~min}$ at $55^{\circ} \mathrm{C}$, and $2 \mathrm{~min}$ at $72^{\circ} \mathrm{C}$, with a $\mathrm{Taq}$ polymerase system (Biotools Labs, Madrid) following the manufacturer's instructions. The screening of the silenced transformants was carried out with the primers IntF (5'-GTG CTA ATC GTG TTA TGC ACA G-3') and Tcbh2 (5'-GAG CTC AAC CCA AAG GAG GG-3'). The PCR conditions were the same described above except that the annealing temperature was $57^{\circ} \mathrm{C}$.

\section{Southern and Northern blot analysis.}

Total DNAs from fungi were extracted following the method of Raeder and Broda (1985). RNA extraction was carried out using the TRIZOL reagent (Invitrogen, Carlsbad, CA, U.S.A.) according to the manufacturer's instructions.

For Southern analysis, $7 \mu \mathrm{g}$ of genomic DNA was digested with BamHI, EcoRI, or XhoI restriction enzymes, electrophoresed on $0.7 \%$ agarose gels, and transferred to a Hybond- $\mathrm{N}^{+}$ membrane (Amersham Biosciences AB, Uppsala, Sweden). For Northern blot analyses, $20 \mu \mathrm{g}$ of total RNA was separated on a $1.2 \%$ formaldehyde-agarose gel and transferred to a Hybond- $\mathrm{N}^{+}$membrane. For both hybridizations, the Thpg $1 \mathrm{cDNA}$ was labeled with ${ }^{32} \mathrm{P}$ and used as a probe. Hybridizations were carried out at $65^{\circ} \mathrm{C}$ for $16 \mathrm{~h}$. Membranes were washed under high-stringency conditions.

\section{Construction of pSIL-PG1.}

Plasmid pSIL (Cardoza et al. 2006) was linearized with SpeI-BamHI and then ligated to a 440-bp SpeI-BamHI fragment of the Thpgl gene. This fragment was in "sense" relative to the orientation of the $t s s 1$ promoter. This construct was later linearized with HindIII-XhoI and then ligated to the same 440-bp Thpgl fragment but in an "antisense" orientation relative to the $t s s 1$ promoter. An intron of $159 \mathrm{bp}$ was introduced between both sense and antisense fragments of the Thpgl gene. The resulting plasmid also contained the terminator region of the $c b h 2$ gene from $T$. reese $i$ and was designated pSIL-PG0. In order to transform this cassette in $T$. harzianum T34, pSIL-PG0 was digested with SacI to isolate the SIL-Thpgl fragment, which was then ligated to the same restriction site of the plasmid pJL43b1 (S. Gutiérrez and Martín, unpublished data), giving rise to the final construct 
pSIL-PG1 $(7.46 \mathrm{~kb})$. This was used to transform $T$. harzianum $\mathrm{T} 34$ by a protoplast-based method described elsewhere (Cardoza et al. 2006).

\section{Enzyme assays.}

Supernatants were dialyzed against milliQ water. PG activity was determined in a colorimetric assay by measuring the release of reducing groups during $\mathrm{PG}$-catalyzed hydrolysis of PGA (Nelson 1957; Somogyi 1952). The reaction mixture $(0.25 \mathrm{ml})$, containing $0.2 \% \mathrm{PGA}$ in $50 \mathrm{mM}$ acetic acid-acetate

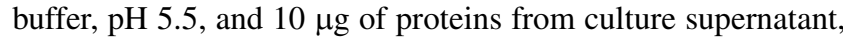
was incubated at $37^{\circ} \mathrm{C}$ for $30 \mathrm{~min}$. One unit of enzymatic activity (U) was defined as $1 \mu \mathrm{mol}$ of galacturonic acid released per minute. Quantitative protein determination was carried out by using the Bradford assay (Bradford 1976). Tests were performed in triplicate and data represent mean values with standard deviation.

The inhibitor activity of different PGIP against the ThPG1 protein was evaluated in the Felice Cervone's laboratory at Universitá di Roma La Sapienza (Rome) following the method described by D'Ovidio and associates (2004b).

\section{Real-time PCR analysis.}

Highly purified, salt-free primers for Thpgl (endop-1, described above; endop-5, 5'-CTT TGG CTT CGT CTT GCC ACC-3'), $\beta$-actin (act-1, 5'-ATC GGT ATG GGT CAG AAG GA-3'; act2, 5'-ATG TCA ACA CGA GCA ATG G-3'), $C H S$ (CS-f, 5'-TTC GGT TAA GCG GCT CAT GA-3'; CS-r, 5'CTC GAG CAC CCT TGT TGT TCT C-3'), and $\beta$-tubulin (tub-f, 5'-TTC TTG CAT TGG TAC ACT AGC G-3'; tub-r, 5'ATC GTT CAT GTT GGA CTC AGC C-3') genes were used and they produced single amplicons of 425, 407, 100, and 71 bp, respectively. PCR conditions were as previously described (Cardoza et al. 2007), except that the annealing temperatures were as follows: Thpg $1,59^{\circ} \mathrm{C} ; \beta$-actin, $55^{\circ} \mathrm{C} ; \mathrm{CHS}, 60^{\circ} \mathrm{C}$; and $\beta$-tubulin, $60^{\circ} \mathrm{C}$.

Thpgl expression was comparatively analyzed in the in vivo T34-tomato-P. ultimum and T34-tomato systems as well as in T34 and the silenced transformants by a semiquantitative realtime method described by Cardoza and associates (2007). The relative expression ratio of Thpgl was expressed in comparison with the reference gene ( $\beta$-actin), according to the equation reported by Pfaffl (2001).

Quantification of wild-type T34 and the ePG5-silenced transformant DNA from the colonized tomato roots was performed using the Stratagene's Brilliant SYBR Green QPCR master mix (Stratagene). The mix was prepared in a $25-\mu 1$ volume by using the following ingredients: $12.5 \mu \mathrm{l}$ of $2 \times$ master mix, $0.25 \mu \mathrm{l}$ of forward primer $(100 \mathrm{nM}), 0.25 \mu \mathrm{l}$ of reverse primer $(100 \mathrm{nM}), 0.375 \mu \mathrm{l}$ of diluted reference dye (300 nM), $50 \mathrm{ng}$ of DNA, and nuclease-free PCR-grade water to adjust the final volume. DNA was extracted from roots $24 \mathrm{~h}$ after inoculation. Amplifications were carried out in the ABI PRISM 7700 (Applied Biosystems, Foster City, CA, U.S.A.) and the thermal cycler was programmed as follows: one cycle of $10 \mathrm{~min}$ at $95^{\circ} \mathrm{C}, 40$ two-step cycles of $15 \mathrm{~s}$ at $95^{\circ} \mathrm{C}$, followed by $1 \mathrm{~min}$ at $60^{\circ} \mathrm{C}$. Cycle threshold values were calculated and the amount of fungal DNA was estimated using standard curves. Values were normalized to the amount of tomato DNA in the samples. Each sample was tested in triplicate.

\section{Microarray analysis.}

Total RNA from the aerial part of an Arabidopsis plant was obtained using the RNeasy plant mini kit (Qiagen, Hilden, Germany). The integrity and pureness of the RNA were determined using the Agilent 2100 Bioanalyzer (Agilent Technolo- gies, Santa Clara, CA, U.S.A.) and cDNA was synthetized with Superscript Choice System for cDNA (Invitrogen). Subsequently, labeled cRNA was obtained from cDNA with an IVT kit (Affymetrix, Santa Clara, CA, U.S.A.) and was used as a probe to hybridize an Affymetrix GeneChip Arabidopsis ATH1 Genome Array, which represents approximately 24,000 genes (Affymetrix). Hybridization and washing of the chips were performed with the procedure described in the GeneChip System Manual of Affymetrix in the Genomic and Proteomic Unit of the University of Salamanca (Salamanca, Spain). Three chips were used per each condition tested.

\section{Biocontrol assays in vivo.}

In vivo tests of the biocontrol ability of T. harzianum T34 or the ePG5-silenced transformant were carried out as previously described by Hermosa and associates (2006). B. cinerea B05.10 conidia were used to infect 4-week-old tomato leaves. Previously, sterilized tomato seed were coated with water (control) or an aqueous suspension containing of the T34 strain or ePG5-silenced transformant at $10^{8}$ conidia/ml. In all, $1 \mathrm{ml}$ of spore suspension served to coat $15 \mathrm{mg}$ of seed that were air dried in an open petri dish overnight in a laminar flow hood.

Two leaves from each plant were inoculated in two points: one leaf with $5 \mu \mathrm{l}$ of a germination solution $(20 \mathrm{mM}$ glucose and $20 \mathrm{mM}$ potassium phosphate) containing $B$. cinerea at 2 $\times 10^{8}$ conidia $/ \mathrm{ml}$ and the other with germination solution alone. Eight plants, one leaf per plant and two inoculation points per leaf, were considered for every condition. Appearance of necrotic spots was assessed 4 days after inoculation. Values of 0 (absence of reaction) to 4 (high necrotic reaction more than $1 \mathrm{~cm}$ diameter) were used to indicate the NSL. Data are presented as mean values \pm standard deviation of three experiments.

\section{Bioinformatics programs and sequence analysis.}

DNA-binding elements were found by looking for consensus sequences described elsewhere or by the MatInspector program on the Genomatix web server. Prediction of the signal peptide cleavage site was searched by the SignalIP 3.0 program, available online from the Swiss Institute of Bioinformatics. Homology analysis and consensus domain search were performed with the Blast program, available online from the National Center for Biotechnology Information. For phylogenetic analysis, sequences were aligned using the CLUSTAL X algorithm (Thompson et al. 1997). The NJ tree was constructed with the MEGA software (Kumar et al. 2001) and a bootstrap analysis of 1,000 replicates was performed.

For microarray analysis, the digitalization of the emitted fluorescent signals after the hybridization was performed with the Gene Array reader (Affymetrix) and the Desktop Mining Solution system (Micro DB 3.0, Data Mining Tool 3.0). This program allows statistical analysis and the identification of the induced and repressed genes in each experimental condition. Background correction, normalization, and expression analysis from the data were performed using the RMA algorithm (Irizarry et al. 2003). The significance of the differential expression in the two conditions compared was determined by statistical analysis performed with SAM (Tusher et al. 2001) and FDR (Benjamini and Hochberg 1995) algorithms, which indicated the proportion of false gene expression data. Microarray data processing was carried out in the Bioinformatic Unit of the University of Salamanca.

\section{ACKNOWLEDGMENTS}

This work has been funded by the Spanish Ministry of Education and Science (AGL2008-0512/AGR), Junta de Castilla y León (research group 
GR67), and European Union (project QLK3-CT-2002-02032). We thank F. Cervone and G. De Lorenzo (Universitá di Roma La Sapienza, Rome) for their support in the PGIP evaluations.

\section{LITERATURE CITED}

Adrianopoulos, A., and Timberlake, W. E. 1994. The Aspergillus nidulans abaA gene encodes a transcriptional activator that acts as a genetics switch to control development. Mol. Cell Biol. 14:2503-2515.

Alfano, G., Lewis Ivey, M. L., Cakir, C., Bos, J. I. B., Miller, S. A., Madden, L. V., Kamoun, S., and Hoitink, H. A J. 2007. Systemic modulation of gene expression in tomato by Trichoderma hamatum 382. Phytopathology 97:429-437.

Annis, S. E., and Goodwin, P. H. 1997. Recent advances in the molecular genetics of plant cell wall-degrading enzymes produced by plant pathogenic fungi. Eur. J. Plant Pathol. 103:1-14.

Belenghi, B., Acconcia, F., Trovato, M., Perazzolli, M., Bocedi, A., Polticelli, F., Ascenzi, P., and Delledonne, M. 2003. AtCYS1, a cystatin from Arabidopsis thaliana, suppresses hypersensitive cell death. Eur. J. Biochem. 270:2593-2604.

Benjamini, Y., and Hochberg, Y.1995. Controlling the false discovery rate: A practical and powerful approach to multiple testing. J. R. Stat. Soc. (Ser. B) 57:289-300.

Bradford, M. M. 1976. A rapid and sensitive method for the quantitation of microgram quantities of protein utilizing the principle of protein-dye binding. Anal. Biochem. 72:248-254.

Brotman, Y., Briff, E., Viterbo, A., and Chet, I. 2008. Role of swollenin, an expansin-like protein from Trichoderma, in plant root colonization. Plant Physiol. 147:779-789.

Cardoza, R. E., Vizcaíno, J. A., Hermosa, M. R., Sousa, S., González, F. J., Llobell, A., Monte, E., and Gutiérrez, S., 2006. Cloning and characterization of the erg1 gene of Trichoderma harzianum: Effect of the erg1 silencing on ergosterol biosynthesis and resistance to terbinafine. Fungal Genet. Biol. 43:164-178.

Cardoza, R. E., Hermosa, M. R., Vizcaíno, J. A., González, F., Llobell, A., Monte, E., and Gutiérrez, S. 2007. Partial silencing of a hydroxymethyl glutaryl-CoA reductase-encoding gene in Trichoderma harzianum CECT 2413 results in a lower level of resistance to lovastatin and lower antifungal activity. Fungal Genet. Biol. 44:269-283.

Carvalho, A., and Moreira, V. 2007. Role of plant lipid transfer proteins in plant cell physiology: A concise review. Peptides 28:1144-1153.

Casasoli, M., Spadoni, S., Lilley, K. S., Cervone, F., De Lorenzo, G., and Mattei, B. 2008. Identification by 2-D DIGE of apoplastic proteins regulated by oligogalacturonides in Arabidopsis thaliana. Proteomics 8:1042-1054.

Cortes, C., Gutierrez, A., Olmedo, V., Inbar, J., Chet, I., and HerreraEstrella, A. 1998. The expression of genes involved in parasitism by Trichoderma harzianum is triggered by a diffusible factor. Mol. Gen. Genet. 260:218-225.

De Lorenzo, G., and Ferrari, S. 2002. Polygalacturonase-inhibiting proteins in defense against phytopathogenic fungi. Curr. Opin. Plant Biol. 5:295-299.

de Vries, R. P., Jansen, J., Aguilar, G., Parenicova, L., Joosten, V., Wülfert, F., Benen, J. A., and Visser, J. 2002. Expression profiling of pectinolytic genes from Aspergillus niger. FEBS (Fed. Eur. Biochem. Soc.) Lett. 530:41-47.

Di Pietro, A. and Roncero, M. I. 1998. Cloning expression, and role in pathogenicity of $\mathrm{pg} 1$ encoding the major extracellular endopolygalacturonase of the vascular wilt pathogen Fusarium oxysporum. Mol. PlantMicrobe Interact. 11:91-98.

Djonovic, S., Vargas, W. A., Kolomiets, M. V., Horndeski, M., Wiest, A., and Kenerley, C. M. 2007. A proteinaceous elicitor Sm1 from the beneficial fungus Trichoderma virens is required for induced systemic resistance in maize. Plant Physiol. 145:875-889.

D’Ovidio, R., Mattei, B., Roberti, S., and Bellincampi, D. 2004a. Polygalacturonases, polygalacturonase-inhibiting proteins and pectic oligomers in plant-pathogen interactions. BBA Proteins Proteomics 1696:237-244.

D’Ovidio, R., Raiola, A., Capodicasa, C., Devoto, A., Pontiggia, D., Roberti, S., Galletti, R., Conti, E., O’Sullivan, D., and De Lorenzo, G. $2004 \mathrm{~b}$. Characterization of the complex locus of bean encoding polygalacturonase-inhibiting proteins reveals subfunctionalization for defense against fungi and insects. Plant Physiol. 135:2424-2435.

Ferrari, S., Vairo, D., Ausubel, F. M. Cervone, F., and De Lorenzo, G. 2003 Tandemly duplicated Arabidopsis genes that encode polygalacturonaseinhibiting proteins are regulated coordinately by different signal transduction pathways in response to fungal infection. Plant Cell 15:93-106.

Götesson, A., Marchall, J. S., Jones, D. A., and Hardham, A. R. 2002. Characterization and evolutionary analysis of a large polygalacturonase gene family in the oomycete plant pathogen Phytophthora cinnamomi. Mol. Plant-Microbe Interact. 15:907-921.

Harman, G. E., Howell, C. R., Viterbo, A., Chet, I., and Lorito M. 2004 Trichoderma species- opportunistic, avirulent plant symbionts. Nat. Rev. Microbiol. 2:43-56.

Heller, G., Adomas, A., Li, G., Osborne, J., van Zyl, L., Sederoff, R., Finlay, R. D., Stenlid, J., and Asiegnu, F. O. 2008. Transcriptional analysis of Pinus sylvestris roots challenged with the ectomycorrhizal fungus Laccaria bicolor. BMC Plant Biol. 25:8-19.

Henrissat, B. 1991. A classification of glycosyl hydrolases based on amino acid sequence similarities. Biochem. J. 280:309-316.

Herbert, C., Jacquet, C., Borel, C., Esquerré-Tugayé, M. T., and Dumas, B. 2002. A cis-acting sequence homologous to the yeast filamentation and invasion response element regulates expression of a pectinase from the bean pathogen Colletotrichum lindemuthianum. J. Biol. Chem. 277:29125-29131.

Hermosa, M. R., Grondona, I., Iturriaga, E. A., Díaz-Mínguez, J. M., Castro, C., Monte, E., and García-Acha, I. 2000. Molecular characterization and identification of biocontrol isolates of Trichoderma spp. Appl. Environ. Microbiol. 66:1890-1898.

Hermosa, M. R., Turrà, D., Fogliano, V., Monte, E., and Lorito, M. 2006. Identification and characterization of potato protease inhibitors able to inhibit pathogenicity and growth of Botrytis cinerea. Physiol. Mol. Plant Pathol. 68:138-148.

Howell, C. R. 1998. The role of antibiosis in biocontrol. Pages 173-185 in: Trichoderma and Gliocladium. Vol. 2. G. E. Harman and C. P. Kubicek, eds. Taylor and Francis, London.

Howell, C. R. 2003. Mechanisms employed by Trichoderma species in the biological control of plant diseases: The history and evolution of current concepts. Plant Dis. 87:4-10.

Isshiki, A., Akimitsu, K., Yamamoto, M., and Yamamoto, H. 2001. Endopolygalacturonase is essential for citrus rot caused by Alternaria citri but not brown spot caused by Alternaria alternata. Mol. Plant-Microbe Interact. 6:749-757

Isshiki, A., Ohtani, M., Kyo, M., Yamamoto, H., and Akimitsu, K. 2003. Green fluorescent detection of fungal colonization and endopolygalacturonase gene expression in the interaction of Alternaria citri with citrus. Phytopathology 93:768-773.

Irizarry, R. A., Hobbs, B., Collin, F., Beazer-Barclay, Y. D., Antonellis, K. J., Scherf, U., and Speed, T. P. 2003. Exploration, normalization, and summaries of high density oligonucleotide array probe level data. Biostatistics 4:249-264.

Jacobs, D. I., van Rijssen, M. S., van der Heijden, R., and Verpoorte, R. 2001. Sequential solubilization of proteins precipitated with trichloroacetic acid in acetone from cultured Catharanthus roseus cell yields $52 \%$ more spots after two-dimensional electrophoresis. Proteomics $1: 1345-1350$

Kemp, G., Stanton, L., Berqmann, C. W., Clay, R. P., Albersheim, P., and Darvill, A. 2004. Polygalacturonase-inhibiting proteins can function as activators of polygalacturonase. Mol. Plant-Microbe Interact. 17:888894.

Kuc, J. 2001. Concepts and direction of induced systemic resistance in plants and its application. Eur. J. Plant Pathol. 107:7-12.

Kumar, S., Tamura, K., Jakobsen, I. B., and Nei, M. 2001. MEGA2: Molecular evolutionary genetics analysis software. Bioinformatics 17:12441245

Kuo, M. H., and Grayhack, E. 1994. A library of yeast genomic MCM1 binding sites contains genes involved in cell cycle control, cell wall and membrane structure, and metabolism. Mol. Cell Biol. 14:348-359.

Limón, M. C., Pintor-Toro, J. A., and Benítez, T. 1999. Increased antifungal activity of Trichoderma harzianum transformants that overexpress a 33-kDa chitinase. Phytopathology 89:254-261.

Lora, J. M., de La Cruz, J., Llobell, A., Benítez, T., and Pintor-Toro, J. A. 1995. Molecular characterization and heterologous expresión o an endo-beta-1,6-glucanase gene from the mycoparasitic fungus Trichoderma harzianum. Mol. Gen. Genet. 247:639-645.

Maldonado-Mendoza, I. E., Dewbre, G. R., Blaylock, L., and Harrison, M J. 2005. Expression of a xyloglucan endotransglucosylase/hydrolase gene, Mt-XTH1, from Medicago truncatula is induced systemically in mycorrhizal roots. Gene 345:191-197.

Marra, R., Ambrosino, P., Carbone, V., Vinale, F., Woo, S. L., Ruocco, M., Ciliento, R., Lanzuise, S., Ferraioli, S., Soriente, I., Gigante, S., Turrà, D., Fogliano, V., Scala, F., and Lorito, M. 2006. Study of the three-way interaction between Trichoderma atroviride, plant and fungal pathogens by using a proteomic approach. Curr. Genet. 50:307-321.

Mohamed, S. A., Christensen, T., and Mikkelsen, J. D. 2003. New polygalacturonases from Trichoderma reesei: Characterization and their specificities to partially methylated and acetylated pectins. Carbohydr. Res. 338:515-524.

Mohamed, S. A., Farid, N. M., Hossiny, E. N., and Bassuiny, R. I. 2006. 
Biochemical characterization of an extracellular polygalacturonase from Trichoderma harzianum. J. Biotechnol. 127:54-64.

Montero-Barrientos, M., Cardoza, R. E., Gutiérrez, S., Monte, E., and Hermosa, R. 2007. The heterologous overexpression of hsp23 a small heat-shock protein gene from Trichoderma virens, confers thermotolerance to T. harzianum. Curr. Genet. 52:45-53.

Mousavi, A., and Hotta, Y. 2005. Glycine-rich proteins: A class of novel proteins. Appl. Biochem. Biotechnol. 120:169-174.

Murashige, T., and Skoog, F. 1962. A revised medium for rapid growth and bioassay with tobacco tissue culture. Physiol. Plant. 15:473-497.

Nelson, N. J. 1957. Colorimetric analysis of sugars. Methods Enzymol. 3:85-86.

Papavizas, G. C. 1985. Trichoderma and Gliocladium: Biology and potential for biological control. Ann. Rev. Phytopath. 23:23-54.

Penttilä, M., Nevalainen H., Ratto M., Salminen E., and Knowles, J. 1987. A versatile transformation system for the cellulolytic filamentous fungus Trichoderma reesei. Gene 61:155-164.

Pfaffl, M.W. 2001. A new mathematical model for relative quantification in real-time RT-PCR. Nucleic Acids Res. 29:2003-2007.

Poinssot, B., Vandelle, E., Bentéjac, M., Adrian, M., Levis, C., Brygoo, Y., Garin, J., Sicilia, F., Coutos-Thévenot, P., and Pugin, A. 2003. The endopolygalacturonase 1 from Botrytis cinerea activates grapevine defense reactions unrelated to its enzymatic activity. Mol. Plant-Microbe Interact. 16:553-564.

Raeder, U., and Broda, P. 1985. Rapid preparation of DNA from filamentous fungi. Lett. Appl. Microbiol. 1:17-20.

Raiola, A., Sella, L., Castiglioni, C., Balmas, V., and Favaron, F. 2008. A single amino acid substitution in highly similar endo-PGs from Fusarium verticillioides and related Fusarium species affects PGIP inhibition. Fungal Genet. Biol. 45:776-789.

Rey, M., Llobell, A., Monte, E., Scala, F., and Lorito, M. 2004. Genomics of Trichoderma. Pages: 225-248 in: Fungal Genomics. Vol. 4. G. G. Khachatourians, ed. Elsevier Science, Amsterdam.

Ridley, B. L., O’Neill, M. A., and Mohnen, D. 2001. Pectins: Structure, biosynthesis, and oligogalacturonide-related signaling. Phytochemistry 57:929-967.

Roper, M. C., Grve, L. C., Warren, J. G., Labavitch, J. M., and Kirkpatrick, B. C. 2007. Xylella fastidiosa requires polygalacturonase for colonization and pathogenicity in Vitis vinifera grapevines. Mol. Plant-Microbe Interact. 20:411-419.

Sambrook, J., and Russel, D. W. 2001. Molecular Cloning. Cold Spring Harbor Laboratory Press, Cold Spring Harbor, NY, U.S.A.

Scott-Craig, J. S., Panaccione, D. G., Cervone, F., and Walton, J. D. 1990. Endopolygalacturonase is not required for pathogenicity of Cochliobolus carbonum on maize. Plant Cell. 2:1191-1200.

Scott-Craig, J. S., Cheng, Y. Q., Cervone, F., De Lorenzo, G., Pitkin, J. W., and Walton, J. D. 1998. Target mutants of Cochliobolus carbonum lacking the two major extracellular polygalacturonases. Appl. Environ. Microbiol. 64:1497-1503.

Shaw, L. J., Morris, P., and Hooker, J. E. 2006. Perception and modification of plant flavonoids signals by rhizosphere microorganisms. Environ. Microbiol. 8:1867-1880.

Shoresh, M., and Harman, G. E. 2008. The molecular basis of shoot responses of maize seedlings to Trichoderma harzianum T22 inoculation of the root: A proteomic approach. Plant Physiol. 147:2147-2163.

Somogyi, N. 1952. Notes on sugar determination. J. Biol. Chem. 195:19-23.

Suárez M. B., Sanz, L., Chamorro, M. I., Rey, M., González, F. J., Llobell, A., and Monte, E. 2005. Proteomic analysis of secreted proteins from
Trichoderma harzianum. Identification of a fungal cell wall-induced aspartic protease. Fungal Genet. Biol. 42:924-934.

Talamo, F., D’Ambrosio, C., Arena, S., Del Vecchio, P., Ledda, L., Zehender, G., Ferrara, L., and Scaloni, A. 2003. Proteins from bovine tissues and biological fluids: Defining a reference electrophoresis map for liver, kidney, muscle, plasma and red blood cells. Proteomics 3:440460.

ten Have, A., Breuil, W. O., Wubben, J. P., Visser, J., and van Kan, J. A 2001. Botrytis cinerea endopolygalacturonase genes are differentially expressed in various plant tissues. Fungal Genet. Biol. 33:97-105.

Thompson, J. D., Gibson, T. J. Plewniak, F., Jeanmougin, F., and Higgins, D. G., and 1997. The CLUSTAL_X windows interface: Flexible strategies for multiple sequence alignment aided by quality analysis tools. Nucleic Acids Res. 25:4876-4882.

Tusher, V. G., Tibshirani, R., and Chu, G. 2001. Significance analysis of microarrays applied to the ionizing radiation response. Proc. Natl. Acad. Sci. U.S.A. 98:5116-5121.

Van Wees, S. C. M., Van der Ent, S., and Pieterse, C. M. J. 2008. Plant immune responses triggered by beneficial microbes. Curr. Opin. Plant Biol. 11:443-448.

Verhagen, B. W. M., Glazebrook, J., Zhu, T., Chang, H., van Loon, L. C., and Pieterse, C. M. J. 2004. The transcriptome of rhizobacteria-induced systemic resistance in Arabidopsis. Mol. Plant-Microbe Interact. 17:895-908.

Vizcaíno, J. A., González, F. J., Suárez, B., Redondo, J., Heinrich, J., Delgado-Jarana, J., Hermosa, R., Gutiérrez, S., Monte, E., Llobell, A., and Rey, M. 2006. Generation, annotation and analysis of ESTs from Trichoderma harzianum CECT 2413. BMC Genet. 7:193.

Vizcaíno, J. A., Redondo, J., Suárez, M. B., Cardoza, R. E., Hermosa, R., González, F. J., Rey, M., and Monte, E. 2007. Generation, annotation and analysis of ESTs from four different Trichoderma strains in conditions related to biocontrol. Appl. Microbiol. Biotechnol. 75:853862.

Willats, W. G. T., McCartney, L., Mackie, W., and Knox, J. P. 2001. Pectin: Cell biology and prospects for functional analysis. Plant Mol. Biol. 47:9-27.

Woo, S. L., Scala, F., Ruocco, M., and Lorito, M. 2006. The molecular biology of the interactions between Trichoderma spp., phytophatogenic fungi, and plants. The nature and application of biocontrol microbes II: Trichoderma spp. Phytopathology 96:181-185.

Wubben, J. P., ten Have, A., van Kan, J. A., and Visser, J. 2000. Regulation of endopolygalacturonase gene expression in Botrytis cinerea by galacturonic acid, ambient $\mathrm{pH}$ and carbon catabolite repression. Curr. Genet. 37:152-157.

Yedidia, I., Benhamou, I. N., and Chet, I. 1999. Induction of defense responses in cucumber plants (Cucumis sativa L.) by the biocontrol agent Trichoderma harzianum. Appl. Environ. Microbiol. 65:1061-1070.

Zeilinger, S., Ebner, A., Marosits, T., Mach, R., and Kubicek, C. P. 2001 The Hypocrea jecorina HAP 2/3/5 protein complex binds to the inverted CCAAT-box (ATTGG) within the $c b h 2$ (cellobiohydrolase II-gene) activating element. Mol. Genet. Genomics 266:56-63.

\section{AUTHOR-RECOMMENDED INTERNET RESOURCES}

Joint Genome Institute genome Trichoderma genome portal: genome.jgi-psf.org/

Matrix Science Mascot software: www.matrix-science.com 